International Journal of Instruction e-ISSN: 1308-1470 • www.e-iji.net

Article submission code: 20191101031325

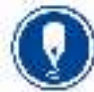

January $2021 \bullet$ Vol.14, No.1

p-ISSN: 1694-609X

pp. $587-598$

Received: 01/11/2019

Revision: 14/07/2020
Accepted: 04/08/2020

OnlineFirst: $31 / 10 / 2020$

\title{
The Increasing Self-Efficacy and Self-Regulated through GeoGebra Based Teaching reviewed from Initial Mathematical Ability (IMA) Level
}

\section{Zetriuslita}

Riau Islamic University, Indonesia, zetriuslita@edu.uir.ac.id

Nofriyandi

Riau Islamic University, Indonesia, nofriyandi@edu.uir.ac.id

Endang Istikomah

Riau Islamic University, Indonesia, endangistikomah@edu.uir.ac.id

The purpose of this study was to identify improvements in Self Efficacy and selfregulated through GeoGebra Based Teaching seen from the level of students' initial mathematical abilities. The research method used was a mixed-method with a sequential explanatory strategy, while the research design was an untreated control group design with pretest and posttest. the experimental group obtained direct learning using GeoGebra software while the control group obtained conventional learning. The population in this study were university students of mathematics education department at the Islamic University of Riau who took the field and space analytic geometry course. The research sample consisted of two classes taken by a cluster random sampling technique. The research instruments used were self-efficacy questionnaire and self-regulated questionnaire for getting quantitative data and interview guidelines for getting qualitative data. Data analysis was carried out quantitatively and qualitatively and data processing used Microsoft excel and SPSS from the quantitative and qualitative data analysis, it was concluded that GeoGebra based teaching was effective in improving students' self-efficacy and self-regulated. Judging from the level of students' initial mathematical abilities, there was an increase in self-efficacy and self-regulated through GeoGebra based teaching from both high, medium and low levels.

Keywords: GeoGebra based teaching, self-efficacy, self-regulated, IMA, teaching

\section{INTRODUCTION}

Technological advances in the era of the industrial revolution 4.0 now no doubt. People no longer need to leave the house to find food or buy something because they can use the Gofood application and food ordered will arrive at your doorstep. Online stores like Tokopedia, Shopee, and others will solve every family's needs and household items will arrive at home using a smartphone. This technological progress has also had an impact

Citation: Zetriuslita, Nofriyandi, \& Istikomah, E. (2021). The Increasing Self-Efficacy and SelfRegulated through Geogebra Based Teaching reviewed from Initial Mathematical Ability (IMA) Level. International Journal of Instruction, 14(1), 587-598. https://doi.org/10.29333/iji.2021.14135a 
on education. Some technologies have helped lecturers and students in learning include GeoGebra software whose application is used in Geometry and Algebra material. Kahoot Software is a game-based learning platform used as educational technology in schools and other educational institutions. the use of technology in learning can improve learning outcomes, the learning becomes effective and efficient and the learning becomes more interesting if it utilizes technology (Husain, 2014). This statement is supported by Stošić (2015) which states that by using the application of educational technology, students can independently master learning material, to choose work accuracy, to repeat learning material, and to know its progress.

Specifically, one of the software often used in learning mathematics is GeoGebra because GeoGebra is easily used and can be downloaded for free. GeoGebra is a computer program that has facilities to visualize or demonstrate mathematical concepts as well as tools to construct mathematical concepts, especially geometry and algebra (Niken, 2017). Hohenwarter \& Fuchs (2004) states that GeoGebra is very useful as a medium of learning mathematics with a variety of activities including; (1) as a medium of demonstration and visualization. In this case, in traditional learning, teachers use GeoGebra to demonstrate and visualize certain mathematical concepts; (2) As a construction aid. GeoGebra is used to visualize the construction of certain mathematical concepts, for example constructing inner and outer circles of triangles, or tangents. In order for this learning with GeoGebra to be influential, self-efficacy and self-regulated learning are needed. Self-efficacy and self-regulated are related to students' ability to trust themselves so that there is no inferiority in dealing with mathematical problems. GeoGebra based teaching is a teaching model that consists of the teacher's explanation of new concepts or skills and the teacher is involved in working with students individually, or in small groups (Watanabe, McLaughlin, Weber, \& Shank, 2013).

Related to self-efficacy, Bandura (1997) explains that one's self-efficacy will affect actions, efforts, perseverance, flexibility in differences, and the realization of the goals of the individual. Someone's self-efficacy will affect the action, effort, perseverance, flexibility in differences, and the realization of the goals of the individual so that selfefficacy often determines the outcome before the action occurs. Chick \& Vincent (2005) states that self-efficacy is a belief in yourself about success in completing a task.

The dimensions of self-efficacy that are used as a basis for measuring individual selfefficacy are ;(1) Magnitude: this dimension is related to the level of difficulty of a task that is believed by someone to be completed. (2) Strength: this dimension relates to the level of strength or weakness of an individual about its abilities. 3) Generality: this dimension relates to the breadth of the field of tasks performed in overcoming or solving problems/tasks, some individuals have limited confidence in various activities and situations. Multon, et al (1991) states that there are five indicators of a person's selfefficacy, namely: (1) Confident of being able to complete certain tasks individually, confident that he is able to complete certain tasks and set tasks (targets) what must be completed. (2) Confident of being able to motivate yourself to take the actions needed to complete the task. (3) Confident of being able to try hard, persevere, and persevere. (4) Confident of being able to survive facing obstacles and difficulties. (5) Confident of 
being able to complete tasks that have a wide or narrow range (specific). Self-efficacy indicators in this study that are used are according to Bandura (1997).

Furthermore, Zimmerman (1989) states that self-regulated is the student's ability to monitor its understanding, to decide when a student ready to be tested, to choose a good information processing strategy. Hadwin and Oshige (2011) describe self-regulation as a regulation that is shared socially. $\mathrm{n}$ this sense, self-regulated is addressed as a concept in which the products are shared in collective and regulatory processes. Self-regulated is composed of the interaction of the belief and its processes with interrelated processes. Self-regulated learning (SRL) is an activity where individuals who actively learn, arrange, determine learning goals, plan and monitor, regulate and control cognition, behavioral motivation, and their environment to achieve their stated goals (Filho, 2001; Pintrich, 2004; Wolters, et al., 2003Zimmerman (2004) defines self-regulated learning as the ability of learners to actively participate in the learning process, both metacognitive, motivation and behavioral. Theoretically the ability to regulate individual self in learning (self-regulated learning) has developed well in adolescence (Wang, 2004). According to Cobb (2003), self-regulated learning influenced by three main factors, namely self-confidence (self-efficacy), motivation and goals. Chung (2000) which states that learning is not only controlled by external aspects but also controlled by internal aspects such as self-regulated.

There are three stages of self-regulated, namely the Planning Phase, at this stage students set steps for learning, namely (1) Analyzing learning tasks, (2) Determining learning objectives, and (3) Planning learning strategies. In the analyzing stage, students implement a plan that is constantly monitored to ensure it leads to learning goals. In the determining stage, students determine how well the learning strategy is chosen and how to achieve these learning goals. The planning stage provides a relationship between the three stages in understanding the lesson (metacognitive knowledge) (Fahinu, 2007).

From the expert opinions above, the self-regulated indicators used in this study are (1) learning initiatives, (2) diagnosing learning needs, (3) setting learning goals, (4) organizing and controlling performance/learning, (5) organize and control cognition, motivation, and Behavior (Self), (6) view difficulties as challenges, (7) find and utilize relevant sources, (8) choose and implement appropriate learning strategies, and (9) evaluate the process and learning outcomes. Mehdinezhad \& Mansouri (2016), Alkharusi, Aldhafri, Al-Hosni, Al-Busaidi, Al-Kharusi, Ambusaidi, \& Alrajhi (2017); Çelik, E., \&Koçak, L (2018), Wahyudiati, Rohaeti, Irwanto, Wiyarsi, \& Sumardi (2020) states that self-efficacy needs to be developed starting from elementary school to university level because self-efficacy is related to self-satisfaction with what has been achieved. Hendikawati, Zahid \&Arifudin, R. (2019); Karami, Sadighi, Bagheri, \&Riasati, (2019) stated that self-regulated can be developed with android or basedcomputer instruction and application of electronic portfolios.

Because of the importance of developing students' self-efficacy and self-regulated, so learning processes need to be designed in accordance with the aim of developing the two attitudes above. With assistance in Direct Instruction, it is expected that self-efficacy and self-regulated can develop and improve both attitudes so that it will have an impact 
on student mathematics learning outcomes. This research will answer problem formulation as follows:

- Are students' self-efficacy who use GeoGebra Based Teaching better than conventional learning?

- 2. Are self-regulated students who use GeoGebra Based Teaching better than conventional learning?

- Are students' self-efficacy using GeoGebra Based Teaching better than conventional learning reviewed from IMA level (high, medium and low)?

- 4. Are students' self-regulated who use GeoGebra Based Teaching better than conventional learning reviewed from the level of IMA (high, medium and low)?

- How is mathematics education students' response on GeoGebra Based Teaching in improving students' self-efficacy and self regulated?

\section{METHOD}

The method used in this study was a mixed-method with a sequential explanatory approach (Creswell, 2014, Cohen, 2007). The research design used in this study was a quasi-experimental type of design with a control group non-equivalent or untreated control group design with pretest and posttest (Setyosari, 2010). The population of this research was mathematics education students from the Riau Islamic consist of 596 students from 14 classes. The sampling technique in this research was used the purposive sampling where the researcher take two classes that have the same ability (homogeneous). Data in this study were collected through filling out self-efficacy and self-regulated questionnaire sheets on GeoGebra Based Teaching in the experimental class and conventional learning in the control class. Data obtained from student selfefficacy and self-regulated questionnaires were analyzed using descriptive statistics and inferential statistics. Data about student opinions were analyzed using descriptivenarrative to complement the results of quantitative analysis. Data analysis in this study used SPSS version 20 and Microsoft Excel 2007 software. The results of the Selfefficacy and self-regulated questionnaire were ordinal data that were transformed into interval data using the Method of Successive Interval (MSI). Then the data is tested based on parametric statistical tests. the increasing analysis of students' self-efficacy and self-regulated using the $t$-test. Then testing the normality of data and homogeneous the experimental class and control class data. If the data are not normally distributed, then the data is processed using a nonparametric test, namely the Mann-Whitney $\mathrm{U}$ test. Conversely, if the data is normally distributed, the Independent-Samples t-test will be used.

\section{Initial Mathematical Ability}

As a basis for grouping students according to the level of IMA (high, medium, low), the researchers took the results of the pretest from the courses that students have studied. To classify the level of academic ability of students, it can be seen in the following Table 1: 
Table 1

Data Grouping Category of IMA Level

\begin{tabular}{ll}
\hline Group & The Interval Score of IMA Level \\
\hline High & $x \geq \bar{x}+$ stdev \\
\hline Medium & $\bar{x}-$ stdev $\leq x<\bar{x}+$ stdev \\
\hline Low & $x<\bar{x}-s t$ dev \\
Source: Arikunto $(2012)$ \\
Note: \\
$x$ & $=$ Student pretest value \\
$\bar{x}$ & $=$ average \\
stdev & $=$ deviation standard
\end{tabular}

Arikunto grouping is modified by taking the percentage of high and low groups is $27 \%$ of many students and the rest is for the moderate group (46\%).

\section{FINDINGS}

\section{The Increasing of Students' Self-Regulated}

The increasing of students' self regulated on experiment class and control class can be seen in Table 2.

Table 2

Description of Students' Self-Regulated Data on the Experimental and Control Classes

\begin{tabular}{llllll}
\hline Class & Mean & Deviation Standard & Minimum & Maximum & Varian \\
\hline Experiment & 0.36 & 0.11 & 0.16 & 0.57 & 0.011 \\
Control & 0.16 & 0.10 & 0.02 & 0.48 & 0.011 \\
\hline
\end{tabular}

From Table 2 above, it can be said that the increase in self-regulated experimental class students was better than the self-regulated control class, where the difference is 0.20 . To make sure this difference is significant, then it is followed by a statistical test that is the difference test. The difference test starts with checking the normality test of data and the homogeneous, if the data is normally distributed and homogeneous, then a statistical ttest is performed. Data normality test results can be seen in the following Table 3:

Table 3

Normality Test for Students' Self-Regulated Data on the Experimental Class and the Control Class

\begin{tabular}{llll}
\hline \multicolumn{4}{l}{ Shapiro-Wilk } \\
\hline Class & Statistic & df & Sig. \\
\hline Control & .967 & 42 & .257 \\
Experiment & .967 & 42 & .265 \\
\hline
\end{tabular}

For the table above was obtained the test of normality of data using Shapiro-Wilk Test. Criteria for testing the normality of students' self-regulated data, namely; Ho is accepted if the probability value (sig.) is greater than $\alpha=0.05$ and Ho is rejected if the probability 
value is smaller than $\alpha=0.05$. Sig. Value $>0.05$, then the control class and experimental class data were normally distributed.

The homogenous test is checked using the Levene Test to determine whether data have the same variant. Homogeneity testing criteria, Ho is accepted if the significant value is greater than $\alpha=0.05$ and Ho is rejected if the significant value is smaller than $\alpha=0.05$. From the Levene test obtained a Significant Value> 0.05 , the student's self-regulated NGain data was homogeneous.

Furthermore, to determine differences between the mean self-regulated student achievement data used t-test, the hypothesis testing, namely:

$\mathrm{H}_{0}$ : There is no difference between Self-regulated experimental class students with selfregulated control class students.

$\mathrm{H}_{1}$ : There is difference between Self-regulated experimental class students with selfregulated control class students

Criteria for testing differences in the results of achieving student learning independence, $\mathrm{H} 0$ is accepted if the significant value is greater than $\alpha=0.05$ and $\mathrm{H} 0$ is rejected if the significant value is smaller than $\alpha=0.05$. The test results can be seen in Table 4 .

Table 4

T-test for Data on Self-Regulated Experimental Class and Control Class Students

\begin{tabular}{lllll}
\hline class & Mean & Deviation Standard & Sig & Decision \\
\hline Experiment & 0.36 & 0.11 & 0.00 & $\mathrm{H}_{0}$ Rejected \\
Control & 0.16 & 0.1 & & \\
\hline
\end{tabular}

Based on table 4, it can be concluded that there is an increase in self-regulated where the experimental class students was better than the control class students.

\section{The Increasing of Students' Self Efficacy}

The results of self-efficacy of the experimental class and control class students can be seen in Table 5.

Table 5

Description of Self-efficacy of the Experimental Class and Control Class Students

\begin{tabular}{llllll}
\hline Class & Mean & Deviation Standard & Minimum & Maximum & Varian \\
\hline Experiment & 0.32 & 0.16 & 0.04 & 0.73 & 0.026 \\
Control & 0.17 & 0.09 & 0.06 & 0.42 & 0.008 \\
\hline
\end{tabular}

Table 5 explains that the increase in self-efficacy of experimental class students was better than control class students. To ensure this conclusion, a parametric statistical in the form of a different test on the increasing of students' self-efficacy was carried out by determining the normality of data and homogeneous, if the data were normal and class have the same variant (homogeneous), the statistics used is the t-test. From the results of the normality test using the Lilliefors test obtained significant for the experimental class and control class smaller than $\alpha=0.05$ so that it can be concluded that the data were not normally distributed.

Because parametric statistical testing was not met, the statistical test used is nonparametric statistics namely the Mann-Whitney U Test. The testing hypotheses namely; 
$\mathrm{H}_{0}$ : There is no difference between self-efficacy of the experimental class student with the control class student

$\mathrm{H}_{1}$ : There is difference between self-efficacy of the experimental class student with the control class student

Criteria for testing the difference from two classes are, Ho is accepted if the significant value is greater than $\alpha=0.05$ and Ho is rejected if the significant value is smaller than $\alpha$ $=0.05$. Mann-Whitney $U$ test results can be seen in the following table 6

Table 6

Mann-Whitney U Test Result of Experimental Class and Control Class Students

\begin{tabular}{lllll}
\hline Class & Mean Rank & Sum Ranks & Asymp sig & Decision \\
\hline Experiment & 55.44 & 2328.50 & 0.00 & \multirow{2}{*}{$\mathrm{H}_{0}$ Rejected } \\
Control & 29.56 & 1241.50 & & \\
\hline
\end{tabular}

Based on table 6, it can be concluded that there was the increasing Self-efficacy at experimental class students where the experimental class was better than the control class.

\section{The Increasing Self-Regulated Based on IMA}

Self-regulated the increasing results based on IMA students can be seen in Table 7.

Table 7

The Increasing of Student Self-Regulated Based on Student IMA

\begin{tabular}{|c|c|c|c|c|}
\hline IMA Level & Class & Mean Rank & Sig. & Decision \\
\hline \multirow[t]{2}{*}{ High } & Experiment( normal distributed) & 0.3873 & 0.000 & \multirow{2}{*}{$\begin{array}{l}\text { There was a } \\
\text { difference }\end{array}$} \\
\hline & $\begin{array}{l}\text { Control (normal distributed) } \\
\text { Experiment (normal distributed) }\end{array}$ & $\frac{0.1573}{27.75}$ & \multirow{2}{*}{0.000} & \\
\hline Medium & Control (not normal distributed) & 13.25 & & $\begin{array}{l}\text { There was a } \\
\text { difference }\end{array}$ \\
\hline Low & $\begin{array}{l}\text { Experiment (normal distributed) } \\
\text { Control (normal distributed) }\end{array}$ & $\begin{array}{l}0.3618 \\
0.1764\end{array}$ & 0.000 & $\begin{array}{l}\text { There was a } \\
\text { difference }\end{array}$ \\
\hline
\end{tabular}

Table 7 illustrates that the increase in Self-regulated experimental class students was better than Self-regulated at control class students based on the three IMA levels (high, medium, and low).

\section{The Increasing Self-Efficacy Based on the Student IMA}

The results of the increasing Self-efficacy based on level IMA students can be seen in Table 8 .

Table 8

The Increasing of Student Self-Efficacy Based on IMA

\begin{tabular}{lllll}
\hline IMA Level & Class & Mean Rank & Sig. & Decision \\
\hline High & Experiment (normal distributed) & 0.289 & 0.000 & There was a difference \\
& Control (normal distributed) & 0.157 & & \\
\hline \multirow{2}{*}{ Medium } & Experiment (normal distributed) & 25.50 & 0.007 & There was a difference \\
& Control (not normal distributed) & 15.20 & & \\
\hline \multirow{2}{*}{ Low } & Experiment (normal distributed) & 0.388 & 0.004 & There was a difference \\
& Control (normal distributed) & 0.176 & & \\
\hline
\end{tabular}

Table 8 illustrates that the increase in Self-efficacy of experimental class students was better than control class Self-efficacy atlow levels, medium level and high level. 


\section{The Interview Results with Students}

The results of interviews with students about the effectiveness of Direct Instruction to increase Self-regulated and Self-efficacy can be seen Table 9.

Table 9

Results of Interviews with Students about GeoGebra Based-Teaching Reviewed on IMA Level

\begin{tabular}{|c|c|c|}
\hline Question & $\begin{array}{l}\text { Students IMA } \\
\text { Level }\end{array}$ & The conclusion of the interview results with students \\
\hline \multirow{3}{*}{$\begin{array}{l}\text { What is your } \\
\text { opinion about } \\
\text { direct } \\
\text { instruction with } \\
\text { the assistance } \\
\text { of GeoGebra in } \\
\text { increasing your } \\
\text { self-regulated } \\
\text { and self- } \\
\text { efficacy? }\end{array}$} & $\begin{array}{l}\text { Tinggi } \\
\text { (Three students } \\
\text { were } \\
\text { Interviewed) }\end{array}$ & $\begin{array}{l}\text { GeoGebra can improve Self-regulated because students understand } \\
\text { what is conveyed by the teacher and assignments can be done again } \\
\text { at home. Discussions with friends can also increase Self-efficacy, } \\
\text { meaning students are asked to come forward to try to work on } \\
\text { problems with the help of GeoGebra that makes more confidence that } \\
\text { usually does not want if asked to the front of the class for } \\
\text { presentations }\end{array}$ \\
\hline & $\begin{array}{l}\text { Medium } \\
\text { (Three students } \\
\text { were } \\
\text { Interviewed) }\end{array}$ & $\begin{array}{l}\text { GeoGebra Based Teaching can improve students' self-regulated. } \\
\text { when studied and tried again at home as explained by the lecturer, it } \\
\text { can give effect to student self-efficacy. This is evidenced by students } \\
\text { who already have the courage to come to the front of the class to } \\
\text { solve problems. Geometry courses are very suitable to be studied by } \\
\text { assisted GeoGebra. Student's confidence increases in working on the } \\
\text { problem, and trying to do it independently }\end{array}$ \\
\hline & $\begin{array}{l}\text { Low } \\
\text { (Three Students } \\
\text { were } \\
\text { Interviewed) }\end{array}$ & $\begin{array}{l}\text { Learning using GeoGebra can make learning independence increase } \\
\text { because with GeoGebra students feel challenged to try it themselves, } \\
\text { and self-confidence becomes better, although there is still fear if } \\
\text { there is a mistake in answering the problem given. }\end{array}$ \\
\hline
\end{tabular}

Sources: The interview results with students that taken three students each of IMA level

From Table 9 above, it can be explained that there was the effectiveness of GeoGebra Based Teaching in improving Self-regulated and Self-efficacy reviewed on the IMA level of students.

\section{DISCUSSION}

From the results of research and analysis of the data obtained, it can be explained that overall the application of GeoGebra Based Teaching can improve students 'Selfregulated and Self-efficacy, while for increasing students' Self-efficacy, GeoGebra Based Teaching can improve Self-efficacy for all levels of IMA. There was an increase in self-regulated and self-efficacy in students because GeoGebra has advantages in demonstrating and visualizing certain mathematical concepts (Hohenwarter \& Fuchs, 2004). The same research about the use of GeoGebra in learning (GeoGebra-assisted Direct Instruction) can improve students' mathematical communication skills in terms of the student's academic level (Zetriuslita, Nofriyandi \& Istikomah, 2019). GeoGebra can be the best media for the teaching and learning process in classrooms (Arbain \& Shukor, 2014). GeoGebra will help students to find out every solution of geometric problems (Tran, Nguyen, Bui, Phan, 2014). The learning and teaching process that uses GeoGebra will enhance various mathematical abilities (Rohaeti \& Bernard, 2018).

The effects of the above visualization, generate a sense of interest and curiosity of students and will affect the confidence and independence of learning. Students want to 
try directly with their own computer to get maximum results. The use of computers in learning mathematics can increase student motivation and confidence (Zulnaidi and Zakaria, 2012). Curiosity can grow with something challenging and interesting given by the teacher or lecturer. One of the challenging and interesting things can be done by using computers (Zetriuslita, 2016).

Research conducted by Liu and Koirala (2009) explained that there was a relationship of confidence and student mathematics learning outcomes. The results of this study imply that student confidence increases with GeoGebra Based Teaching will also have an impact on improving learning outcomes. Self efficacy also correlates with critical thinking (Dehghani, Sani, Pakmehr \& Malekzadeh, 2011). Students who have critical thinking skills correlate with learning outcomes (Zetriuslitas, 2018; Risnawati, Andrian, Azmi, \& Nurdin, 2019). About GeoGebra, Hutkemri (2017) states that GeoGebra can improve students' conceptual, procedural knowledge and have an impact on improving student mathematics learning outcomes.

From the results of interviews for each level of IMA, information was obtained that there was a learning effect using GeoGebra Based Teaching on students' self-regulated and self-efficacy. Students stated that by learning GeoGebra Based Teaching they were challenged to be able to try themselves (Self-regulated) in answering questions related to the material provided. This is due to the visualization of GeoGebra that makes students want to also get results with their own efforts so that it fosters self-confidence (Selfefficacy).The application of GeoGebra Based Teaching is supported by Kanfush (2014) which states that direct instruction has long been considered an appropriate method for teaching students.

\section{CONCLUSION}

From the results of data analysis, it can be concluded that the increasing and achievement of students 'self-regulated and self-efficacy through GeoGebra Based Teaching was better than the increasing and achievement of students' self-regulated and self-efficacy through conventional learning, both overall and based on IMA level. GeoGebra Based Teaching gives comfortable experiences to students in mastering the mathematics materials so that the students have high curiosity and always think to try something new of the mathematic problem.

\section{RECOMMENDATION}

GeoGebra software is recommended for teaching and learning in the classroom so that it can be explored for increasing or improving some of the ability in mathematics subject in various level of school. Researchers, lecturers, and teacher can benefit this software for developing the new experience with technology in teaching and learning process.

\section{REFERENCES}

Alkharusi, H., Aldhafri, S., Al-Hosni, K., Al-Busaidi, S., Al-Kharusi, B., Ambusaidi, A., \& Alrajhi, M. (2017). Development and validation of a scale for measuring mathematics teaching self-efficacy for teachers in the Sultanate of Oman. International Journal of Instruction, 10(3), 143-158. https://doi.org/10.12973/iji.2017.10310a. 
Arbain, N., \& Shukor, N. A. (2015). The effects of GeoGebra on students achievement. Procedia - Social and Behavioral Sciences, 172, 208 - 214

Arikunto, S. (2012). Prosedur penelitian. Suatu Pendekatan Praktek. Jakarta: Rineka Cipta.

Bandura, A. (1997). Self-efficacy: The exercise of control. New York: Freeman.

Boateng, P., \& Sekyere, F. O. (2018). exploring in-service teachers' self-efficacy in the kindergarten classrooms in Ghana. International Journal of Instruction, 11(1), 239-254. https://doi.org/10.12973/iji.2018.11117a.

Cleary, T, J., \& Peggy, P. P. (2009) Self-regulation, motivation, and math achievement in middle school. Journal of School Psychology, 47(5), 291-314.. https://doi.org/10.1016/j.jsp.2009.04.002.

Cobb, R. J. (2003). The relationship between self-regulated learning behaviors and academic performance in web-based course (Unpublished doctoral dissertation). Virginia: Blacksburg

Chung, M. K. (2000). The development of self-regulated learning. The Institute of Asia Pacific Education Development, 1(1), 55-56.

Çelik, E., \& Koçak, L. (2018). Suppression effect of sensation seeking on the relationship between general self-efficacy and life satisfaction among emerging adults. Int. Journal of Instruction, 11(4), 337-352. https://doi.org/10.12973/iji.2018.11422a.

Cohen, L, Manion, L., \& Morrison, K. (2007). Research methods in education. Routledge.

Creswell, J. W (2014). Research design: Qualitative, quantitative and mixed method approaches. SAGE.

Dehghani, M., Sani, H. J., Pakmehr, H., \& Malekzadeh, A. (2011). Relationship between students' critical thinking and self-efficacy beliefs in Ferdowsi University of Mashhad, Iran. Procedia Social and Behavioral Sciences, 15, 2952-2955.

Dikovic, L. (2009). Applications GeoGebra into teaching some topics of mathematics at the college level. Computer Science and Information Systems, 6(2), 191-203

Dwi, J. P. (2016). Penerapan Pembelajaran Matematika Menggunakan Aplikasi GeoGebra untuk Meningkatkan Hasil Belajar Siswa Materi Sifat-sifat Tabung dan Prisma Kelas V SD Kanisius Jetisdepok. Yogyakarta: Universitas Sanata Dharma.

Fahinu. (2007). Meningkatkan kemampuan berpikir kritis dan kemandirian belajar matematika pada mahasiswa melalui pembelajaran generatif. Bandung. Universitas Pendidikan, Indonesia.

Filho, M. K. C. (2001). A review on theories of self-regulation of learning. School Educ. 3(50), 437-445.

Greco, R. D., Bernadowski, C., \& Parker,S. (2018). Using illustrations to depict preservice science teachers' self-efficacy: A case study. International Journal of Instruction, 11(2), 75-88. https://doi.org/10.12973/iji.2018.1126a. 
Hake, R. R. (1998). Interactive-engagement versus traditional method: A six-thousandstudent survey of mechanics test data for introductory physics course. American Journal of Physics, 66(1), 64-74.

Hendikawati, P., Zahid, M. Z., \& Arifudin, R. (2019). Android-based computer assisted instruction development as a learning resource for supporting self-regulated learning. Int. Journal of Instruction, 12(3), 389-404. https://doi.org/10.29333/iji.2019.12324a.

Hohenwarter, M., \& Fuchs, K. (2004). Combination of dynamic geometry, algebra, and calculus in the software system GeoGebra. In Computer Algebra Systems and Dynamic Geometry Systems in Mathematics Teaching Conference (pp. 128-133). Pecs, Hungary.

Husain, C. (2014). Pemanfaatan teknologi informasi dan komunikasi dalam pembelajaran di SMA Muhammadiyah Tarakan. Jurnal Kebijakan dan Pengembangan Pendidikan. 2(2), 184-192

Kanfush, P. M. (2014). Dishing direct instruction: Teachers and parents tell all. The Qualitative Report, 19(1), 1-13.

Karami, S., Sadighi, F., Bagheri, M. S., \& Riasati, M. J. (2019). The impact of application of electronic portfolio on undergraduate English majors' writing proficiency and their self-regulated learning. International Journal of Instruction, 12(1), 1319-1334. https://doi.org/10.29333/iji.2019.12184a.

Liu, X., \& Koirala, H. (2009). The effect of mathematics self-efficacy on mathematics achievement of high school students. NERA Conference Proceeding, 30, 1-13.

Marcou, A., \& Philippou, G. (2005). Motivational beliefs, self-regulated learning and mathematical problem solving. Proceedings of the 29th Conference of the International Group for the Psychology of Mathematics Education, 3, 297-304.

Multon, K. D., Brown, S. D., \& Lent, R. W. (1991). Relation of self-efficacy beliefs to academic outcomes: A meta-analytic investigation. Journal of Counseling Psychology, 38, 30-3, https://doi.org/10.1037/0022-0167.38.1.30.

Niken, T. F. (2017). Efektivitas Penggunaan Program GeoGebra pada Pembelajaran Matematika Materi Geometri terhadap Motivasi dan hasil Belajar di Kelas X SMA BOPKRI. Yogyakarta: Universitas Sanata Dharma.

Pintrich, P. R. (2004). A conceptual framework for assessing motivation and selfregulated learn in college students. Educational Psychology Review, 16(4), 386-407.

Risnawati, Andrian, D., Azmi, M. P., Amir, Z., \& Nurdin, E. (2019). Development of a definition maps-based plane geometry module to improve the student teachers' mathematical reasoning ability. International Journal of Instruction, 12(3), 1-15

Rohaeti, E. E., \& Bernard, M. (2018). The students' mathematical understanding ability through scientific-assisted approach of GeoGebra software. Infinity, 7(2), 165-172. https://doi.org/10.22460/infinity.v7i2.p165-172.

Setyosari, P. (2010). Metode Penelitian Pendidikan dan Pengembangan. Jakarta: Prenada Media Group. 
Stosic, L. (2015). The importance of educational technology in teaching. International Journal of Cognitive Research in Science, Engineering and Education. 3(1), 111-114

Sugiyono. (2011). Statistika untuk Penelitian. Bandung: Alfabeta.

Tran, T., Nguyen, N. G., Bui, M. D., \& Phan, A. H. (2014). Discovery learning with the help of the GeoGebra dynamic geometry software. International Journal of Learning, Teaching and Educational Research, 7(1) 1, 44-57

Wahyudiati, D., Rohaeti, E., Irwanto, Wiyarsi, A., \& Sumardi, L. (2020). Attitudes toward chemistry, self-efficacy, and learning experiences of pre-service chemistry teachers: Grade level and gender differences. International Journal of Instruction, 13(1), 235-254. https://doi.org/10.29333/iji.2020.13116a.

Wang, B. (2004). Self-regulated learning strategies and self-efficacy beliefs of children learning English as a second language (Unpublished doctoral dissertation). Ohio State University, Columbus, Ohio.

Watanabe, M., McLaughlin, T. F., Weber, K. P., \& Shank, L. (2013). The effects of using direct instruction to teach coin counting and giving. International Journal of Basic and Applied Science 2(1), 150-159.

Wolters, C. A, Pintrich, P. R., \& Karabenick, S. A. (2003). Assessing academic selfregulated learning. Conference on Indicators of Positive Development: Definitions, Measures, and Prospective Validity, 1-63

Zetriuslita. (2016). Profil sikap ilmiah rasa ingin tahu (curiosity) Matematis mahasiswa. Jurnal Ilmu Pendidikan (JIP), 8(1), 41-46.

Zetriuslita, Wahyudin, \& Dahlan, J., A (2018). Association among mathematical critical thinking skill, communication, and curiosity attitude as the impact of problem-based learning and cognitive conflict strategy (PBLCCS) in number theory course. Infinity Journal of Mathematics Education, 7(1), 16-24

Zetriuslita, Nofriyandi, \& Istikomah, E. (2019). The effectiveness of GeoGebra-assisted direct instruction learning in improving students' mathematical communication skill viewed from academic level. Journal of Physics: Conference Series. 1315012049. https://doi.org/10.1088/1742-6596/1315/1/012049.

Zimmerman, B. J. (1989) A social cognitive view of self-regulated academic learning. Journal of Educational Psychology, 81(3), 29-33

Zimmerman, B. J. (2004). A social cognitive view of self-regulated academic learning. Journal of Educational Psychology, 4(2), 22-63.

Zulnaidi, H., \& Zakaria, E (2012). The effect of using GeoGebra on conceptual and procedural knowledge of high school mathematics students. The Journal Asian Social Science; 8(11), 102-106 